\title{
Effect of sintering temperature on microstructure, chemical stability, and electrical properties of transition metal or Yb-doped $\mathrm{BaZr}_{0.1} \mathrm{Ce}_{0.7} \mathrm{Y}_{0.1} \mathrm{M}_{0.1} \mathrm{O}_{3-\delta}(\mathrm{M}=\mathrm{Fe}, \mathrm{Ni}, \mathrm{Co}$, and $\mathrm{Yb})$
}

\author{
Behzad Mirfakhraei, Farshid Ramezanipour, Scott Paulson, Viola Birss and Venkataraman Thangadurai *
}

Department of Chemistry, University of Calgary, Calgary, AB, Canada

\section{Edited by:}

Fanglin Chen, University of South

Carolina, USA

\section{Reviewed by:}

Hongying Hou, Kunming University of Science and Technology, China

Chao Xu, North China Electric Power University, China

Shumin Fang, University of South

Carolina, USA

*Correspondence:

Venkataraman Thangadurai,

Department of Chemistry, University of Calgary, 2500 University Dr. NW,

Calgary, ABT2N 1N4, Canada

e-mail:vthangad@ucalgary.ca

\begin{abstract}
Perovskite-type $\mathrm{BaZr}_{0.1} \mathrm{Ce}_{0.7} \mathrm{Y}_{0.1} \mathrm{M}_{0.1} \mathrm{O}_{3-\delta}(\mathrm{M}=\mathrm{Fe}, \mathrm{Ni}, \mathrm{Co}$, and $\mathrm{Yb}$ ) (BZCY-M) oxides were synthesized using the conventional solid-state reaction method at $1350-1550^{\circ} \mathrm{C}$ in air in order to investigate the effect of dopants on sintering, crystal structure, chemical stability under $\mathrm{CO}_{2}$ and $\mathrm{H}_{2} \mathrm{~S}$, and electrical transport properties. The formation of the single-phase perovskite-type structure with an orthorhombic space group Imam was confirmed by Rietveld refinement using powder $\mathrm{X}$-ray diffraction for the $\mathrm{Fe}, \mathrm{Co}, \mathrm{Ni}$, and $\mathrm{Yb}$-doped samples. The BZCY-Co and BZCY-Ni oxides show a total electrical conductivity of 0.01 and $8 \times 10^{-3} \mathrm{~S} \mathrm{~cm}^{-1}$ at $600^{\circ} \mathrm{C}$ in wet $\mathrm{H}_{2}$ with an activation energy of 0.36 and $0.41 \mathrm{eV}$, respectively. Scanning electron microscope and energy-dispersive $\mathrm{X}$-ray analysis revealed $\mathrm{Ba}$ and Co-rich secondary phase at the grain-boundaries, which may explain the enhancement in the total conductivity of the BZCY-Co. However, ex-solution of Ni at higher sintering temperatures, especially at $1550^{\circ} \mathrm{C}$, decreases the total conductivity of the BZCY-Ni material. The $\mathrm{Co}$ and $\mathrm{Ni}$ dopants act as a sintering aid and form dense pellets at a lower sintering temperature of $1250^{\circ} \mathrm{C}$. The Fe, Co, and Ni-doped BZCY-M samples synthesized at $1350^{\circ} \mathrm{C}$ show stability in $30 \mathrm{ppm} \mathrm{H}_{2} \mathrm{~S} / \mathrm{H}_{2}$ at $800^{\circ} \mathrm{C}$, and increasing the firing temperature to $1550^{\circ} \mathrm{C}$, enhanced the chemical stability in $\mathrm{CO}_{2} / \mathrm{N}_{2}(1: 2)$ at $25-900^{\circ} \mathrm{C}$. The BZCY-Co and BZCY-Ni compounds with high conductivity in wet $\mathrm{H}_{2}$ could be considered as possible anodes for intermediate temperature solid oxide fuel cells.
\end{abstract}

Keywords: high temperature proton conductor, chemical stability, doped barium cerate, SOFC, anode material

\section{INTRODUCTION}

Research on perovskite-type $\left(\mathrm{ABO}_{3}\right)$ acceptor-doped $\mathrm{BaCeO}_{3}$ materials has been accelerated in recent years due to their attractive high protonic conductivity under $\mathrm{H}$-containing atmospheres (Schober, 2003; Tao and Irvine, 2006; Zuo et al., 2006b; Yang et al., 2009, 2010). Acceptor doping of the perovskite creates oxide ion vacancies $\left(\mathrm{V}_{\mathrm{o}}^{\bullet \bullet}\right)$ in the perovskite structure. Incorporation of $\mathrm{H}_{2} \mathrm{O}$ into these $\left(\mathrm{V}_{\mathrm{o}}^{\bullet}\right)$ sites will create mobile proton charge carriers $\left(\mathrm{H}^{+}\right)$(Iwahara et al., 1981). These physical properties make them attractive membranes for proton conducting solid oxide fuel cells (H-SOFCs), $\mathrm{H}_{2}$ pumps, gas separation, and steam electrolyzers (Schober, 2003). Despite the high protonic conduction in wet reducing atmospheres, $\mathrm{BaCeO}_{3}$ suffers from chemical instability in $\mathrm{CO}_{2}$ atmospheres, due to $\mathrm{BaCO}_{3}$ formation (Zuo et al., 2006b; Tu et al., 2009). The reaction may proceed to the complete decomposition of $\mathrm{BaCeO}_{3}$ into $\mathrm{CeO}_{2}$ and $\mathrm{BaCO}_{3}$ under $\mathrm{CO}_{2}$ at elevated temperatures (Trobec and Thangadurai, 2008). While hydrocarbons are the ultimate fuels for SOFCs and for $\mathrm{H}_{2}$ production, $\mathrm{CO}_{2}$ exposure is inevitable for anode and electrolyte materials in $\mathrm{H}$-SOFCs. It has been shown that partial Zr-substitution of the Cesite enhances the chemical stability in $\mathrm{CO}_{2}$ (Ryu and Haile, 1999), with the $\mathrm{Zr}$-dopant significantly suppressing the proton conductivity (Pergolesi et al., 2010). The $\mathrm{Zr}$-doped $\mathrm{BaCeO}_{3}$ was found to decompose in $\mathrm{CO}_{2}$ at $900^{\circ} \mathrm{C}$ (Zhong, 2007), while it was reported to partially decompose under $20 \% \mathrm{CO}_{2}$ at the same temperature (Zuo et al., 2006a).

To overcome the lower ionic conductivity, acceptor dopants have been introduced to the B-site in order to increase the $\mathrm{V}_{\mathrm{o}}^{\bullet \bullet}$ and subsequent proton concentration upon $\mathrm{H}_{2} \mathrm{O}$ incorporation into the oxide ion vacancies through reaction (1) (Iwahara et al., 1981; Knight, 1999; Kreuer, 1999; Shimura et al., 2005; Azimova and McIntosh, 2009; Ricote and Bonanos, 2010; Zhao et al., 2010),

$$
\mathrm{H}_{2} \mathrm{O}_{(g)}+\mathrm{V}_{\mathrm{o}}^{\bullet \bullet}+\mathrm{O}_{\mathrm{o}}^{x} \rightarrow 2 \mathrm{OH}_{\mathrm{o}}^{\bullet}
$$

where $\mathrm{O}_{\mathrm{o}}^{x}$ and $\mathrm{OH}_{\mathrm{o}}^{\bullet}$ represent oxygen ions in the lattice position and proton attached to lattice oxygen site, respectively. $\mathrm{BaZr}_{0.1} \mathrm{Ce}_{0.7} \mathrm{Y}_{0.2} \mathrm{O}_{3-\delta}$ (BZCY) is a frontier compound that has out-performed conventional electrolytes at $300-550^{\circ} \mathrm{C}$ (Zuo et al., 2006b). $\mathrm{BaZr}_{0.1} \mathrm{Ce}_{0.7} \mathrm{Y}_{0.1} \mathrm{Yb}_{0.1} \mathrm{O}_{3-\delta}$ (BZCY-Yb) showed a proton conductivity more than two times that of the BZCY parent compound (Yang et al., 2009). This has initiated several studies aimed at investigating the properties of BZCY-Yb under SOFC anode conditions and attempting to further enhance its catalytic performance (Yang et al., 2010; Liu et al., 2011; Zhang et al., 2012; Nguyen and Yoon, 2013). SOFCs utilizing Ni/BZCY-Yb composites as the anode material have produced a power density of $1.1 \mathrm{~W} \mathrm{~cm}^{-2}$ at $750^{\circ} \mathrm{C}$. Here, we show the results of incorporating a new series 
of dopants into the B-site of BZCY, resulting in the enhancement of both the electrical conductivity and material sinterability. BZCY-Co, prepared at $1550^{\circ} \mathrm{C}$, shows the highest total electrical conductivity of $0.01 \mathrm{~S} \mathrm{~cm}^{-1}$ at $600^{\circ} \mathrm{C}$ in wet $\mathrm{H}_{2}$.

\section{MATERIALS AND METHODS}

Perovskites having the nominal chemical formula $\mathrm{BaZr}_{0.1} \mathrm{Ce}_{0.7} \mathrm{Y}_{0.1}$ $\mathrm{M}_{0.1} \mathrm{O}_{3-\delta}$ (BZCY-M) $(\mathrm{M}=\mathrm{Fe}, \mathrm{Ni}, \mathrm{Co}$, and $\mathrm{Yb})$ were synthesized by the conventional solid-state method in air. Stoichiometric amounts of $\mathrm{BaCO}_{3}, \mathrm{ZrO}_{2}, \mathrm{CeO}_{2}, \mathrm{Y}_{2} \mathrm{O}_{3}, \mathrm{Fe}_{2} \mathrm{O}_{3}, \mathrm{NiO}$, $\mathrm{Co}\left(\mathrm{NO}_{3}\right)_{2} \cdot 6 \mathrm{H}_{2} \mathrm{O}$, and $\mathrm{Yb}_{2} \mathrm{O}_{3}$ were ball milled with zirconia balls for $6 \mathrm{~h}$ at $200 \mathrm{rpm}$ in isopropanol. The dried powder mixtures were then calcined at $1100^{\circ} \mathrm{C}$ for $24 \mathrm{~h}$ in air. After cooling and ball-milling for $6 \mathrm{~h}$, powder X-ray diffraction (PXRD) analysis [Bruker D8 powder X-ray diffractometer ( $\mathrm{Cu} \mathrm{K \alpha}, 40 \mathrm{kV} ; 40 \mathrm{~mA})$ ] at room temperature with a $2 \theta$ step scan width of 0.02 and a counting time of $6 \mathrm{~s}$ was carried out on each sample. The calcination and subsequent ball-milling process was repeated two more times at $1100^{\circ} \mathrm{C}$ for 12 and $24 \mathrm{~h}$, before a final heat treatment at $1350^{\circ} \mathrm{C}$ for $6 \mathrm{~h}$. The PXRD data were then used for the analysis of the crystal structures of the Fe, Co, and Ni-doped samples. For comparison, the parent compound (BZCY-Yb) was also synthesized using a similar synthesis method and studied by PXRD. Rietveld refinements were performed using the program GSAS (Larson and Von Dreele, 1994) and EXPGUI interface (Toby, 2001).

For conductivity measurements, the ball milled powders were uniaxially pressed using a $13 \mathrm{~mm}$ die at $120 \mathrm{MPa}$. The pressed samples were sintered at 1250,1350 , and $1550^{\circ} \mathrm{C}$ for $12 \mathrm{~h}$. Pt paste (LP A88-11S, Heraeus Inc., Germany) was painted on the two sides of the cylindrical samples to serve as the electrodes. The conductivity of the samples was measured using a two-electrode four-probe conductivity measurement setup using the impedance spectroscopy technique, employing either a Solartron 1287/1255 potentiostat/galvanostat/impedance analyzer or a Solartron 1260 impedance analyzer in air and humid $\mathrm{H}_{2}$ (3 vol. $\% \mathrm{H}_{2} \mathrm{O}$ ).

The in situ $\mathrm{CO}_{2}$ stability test was performed on powdered samples (weight: 10-20 mg; particle size: $<150 \mu \mathrm{m}$ ) using a Mettler Toledo thermogravimetric analyzer (TGA) in $\mathrm{CO}_{2} / \mathrm{N}_{2}(1: 2$ ratio). The samples powders were passed through a sieve with mesh number 100 (Endecotts Ltd.) to remove any particle larger than $150 \mu \mathrm{m}$. The chemical stability of the materials in the $\mathrm{H}_{2} \mathrm{~S}$ containing atmosphere was studied at $800^{\circ} \mathrm{C}$ for $24 \mathrm{~h}\left(10^{\circ} \mathrm{C} / \mathrm{min}\right)$ in $30 \mathrm{ppm} \mathrm{H}_{2} \mathrm{~S}$ in dry $\mathrm{H}_{2}$. The morphology and composition of the samples were determined using a Philips XL 30 scanning electron microscope (SEM) with energy-dispersive X-ray analysis (EDX) capabilities, and also a Zeiss Sigma VP field-emission SEM equipped with an Oxford INCA X-Act EDX unit. The distribution of elements in the samples was also established using wavelength dispersive spectrometry (WDS), employing a JEOL JXA-8200 electron microprobe.

\section{RESULTS}

\section{STRUCTURAL CHARACTERIZATION}

Table 1 shows the Rietveld refinement results for $\mathrm{BaZr}_{0.1} \mathrm{Ce}_{0.7} \mathrm{Y}_{0.1}$ $\mathrm{M}_{0.1} \mathrm{O}_{3-\delta}(\mathrm{M}=\mathrm{Fe}, \mathrm{Co}, \mathrm{Ni}$, and $\mathrm{Yb})$. The refinement XRD profiles
Table 1 | Atomic parameters for the $\mathrm{BaZr}_{0.1} \mathrm{Ce}_{0.7} \mathrm{Y}_{0.1} \mathrm{M}_{0.1} \mathrm{O}_{3-\delta}(\mathrm{M}=\mathrm{Fe}$, Co, $\mathrm{Ni}$, and $\mathrm{Yb}$ ) phases.

\begin{tabular}{lllll}
\hline Space group Imam & BZCY-Fe & BZCY-Co & BZCY-Ni & BZCY-Yb \\
\hline Ba & & & & \\
$x$ & 0.5 & 0.5 & 0.5 & 0.5 \\
$y$ & $0.2485(4)$ & $0.2522(8)$ & $0.2471(5)$ & $0.256(1)$ \\
$z$ & 0.25 & 0.25 & 0.25 & 0.25 \\
$U_{\text {iso }}\left(\AA^{2}\right)$ & $0.0336(7)$ & $0.034(1)$ & $0.0376(8)$ & $0.031(1)$ \\
Occupancy & 1 & 1 & 1 & 1 \\
Ce/Zr/Y/M (0.7/0.1/0.1/0.1) & & & \\
$x$ & 0.25 & 0.25 & 0.25 & 0.25 \\
$y$ & 0.75 & 0.75 & 0.75 & 0.75 \\
$z$ & 0.25 & 0.25 & 0.25 & 0.25 \\
$U_{\text {iso }}\left(\AA^{2}\right)$ & $0.0291(6)$ & $0.023(1)$ & $0.0197(8)$ & $0.028(1)$ \\
Occupancy & 1 & 1 & 1 & 1 \\
O1 & & & & \\
$x$ & 0.5 & 0.5 & 0.5 & 0.5 \\
$y$ & $0.309(2)$ & $0.330(4)$ & $0.294(2)$ & $0.25(2)$ \\
$z$ & 0.75 & 0.75 & 0.75 & 0.75 \\
$U_{\text {iso }}\left(\AA^{2}\right)$ & $0.046(7)$ & $0.021(7)$ & $0.063(5)$ & $0.08(1)$ \\
Occupancy & 0.95 & 0.95 & 0.925 & 0.95 \\
O2 & & & & \\
$x$ & $0.279(2)$ & $0.276(3)$ & $0.271(1)$ & $0.272(4)$ \\
$y$ & 0 & 0 & 0 & 0 \\
$z$ & 0.5 & 0.5 & 0.5 & 0.5 \\
$U_{\text {iso }}\left(\AA^{2}\right)$ & $0.073(4)$ & $0.066(6)$ & $0.053(3)$ & $0.11(1)$ \\
Occupancy & 0.975 & 0.975 & 0.9625 & 0.975 \\
\hline
\end{tabular}

are shown in Figure 1, with the formation of the orthorhombic space group Imam, thus confirmed. The crystal structure involves $\mathrm{Ce}, \mathrm{Zr}, \mathrm{Y}$, and $\mathrm{M}$ sharing the same lattice position. These cations are coordinated by six oxygen ions that form an octahedral geometry, as shown in Figure 2A. Each oxygen anion is bonded to two cations on both sides, leading to corner-sharing between the octahedra (Figure 2A). There are spaces between these octahedra where the large $\mathrm{Ba}^{2+}$ cations reside (Figures 2A,B). The $\mathrm{Ce}(\mathrm{ZrYM}) \mathrm{O} 6$ octahedron is tilted in a direction opposite to all of its nearest neighbors. Therefore, if an octahedron is tilted to the right, all of the nearest neighbor octahedra will be tilted to the left. The $\mathrm{Ba}$ atoms have 12 oxygen anions as their nearest neighbors (Figure 2C).

The unit cell volumes for the $\mathrm{M}=\mathrm{Fe}$ and Co phases are similar to each other (Figure 1), while there is a pronounced increase for the Ni-containing oxide and also a further increase for the $\mathrm{Yb}$ doped material. These observations are consistent with the large ionic radii of $\mathrm{Ni}^{2+}$ and $\mathrm{Yb}^{3+}$ (Shannon, 1976) and support the hypothesis of the substitution of the transition metal dopants in the $\mathrm{B}(\mathrm{Ce})$-site in BZCY. However, the unit cell volume for all four phases is markedly smaller than that of the un-doped $\mathrm{BaCeO}_{3}$, which is $339.86 \AA^{3}$ (Knight and Bonanos, 1995), due to the effect of the small $\mathrm{Zr}^{4+}$ ion in the doped phases.

\section{ELECTRICAL CONDUCTIVITY}

Typical AC impedance plots obtained at 484 and $837^{\circ} \mathrm{C}$ for $\mathrm{BaZr}_{0.1} \mathrm{Ce}_{0.7} \mathrm{Y}_{0.1} \mathrm{Ni}_{0.1} \mathrm{O}_{3-\delta}$ in $\mathrm{H}_{2}\left(+3\right.$ vol.\% $\left.\mathrm{H}_{2} \mathrm{O}\right)$ are shown in 

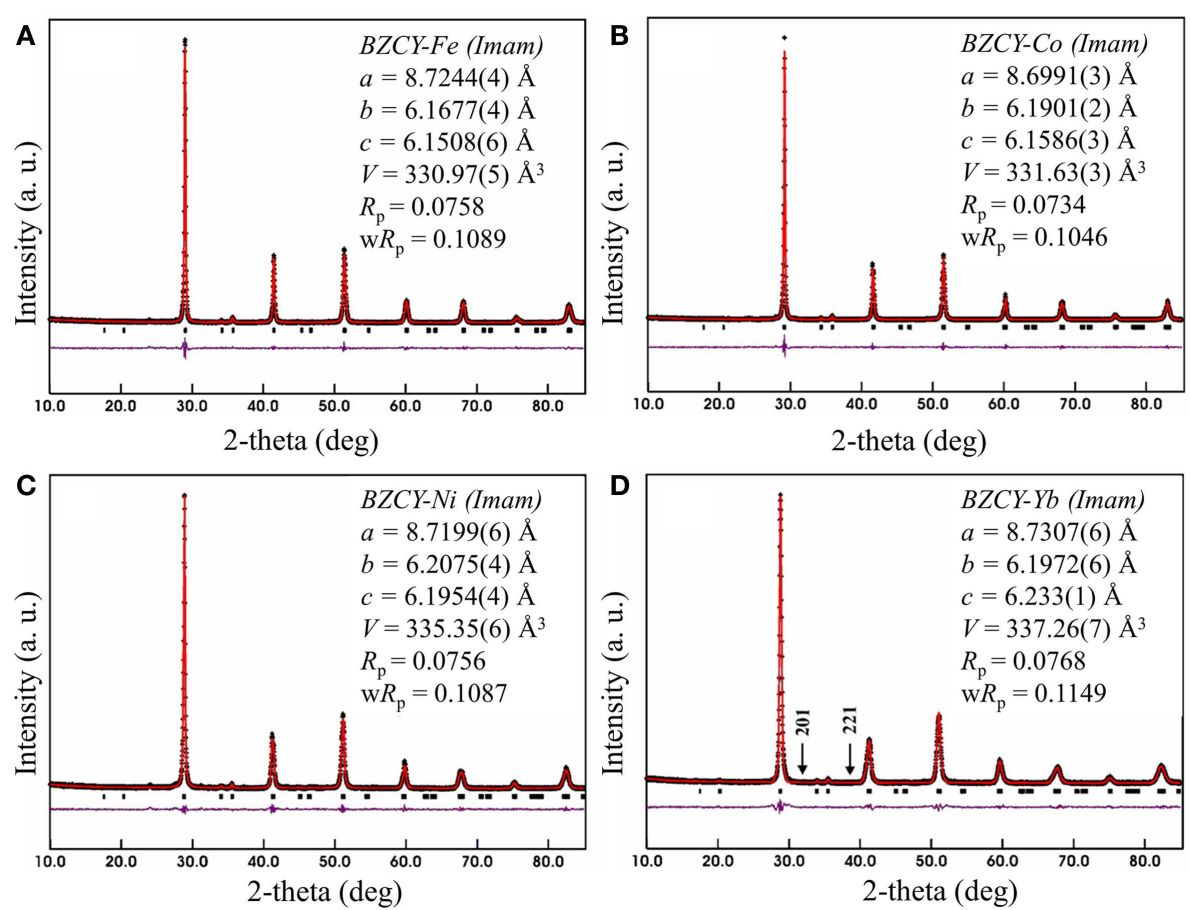

FIGURE 1 | Rietveld refinement profiles for $B a Z r_{0.1} C_{0.7} \mathbf{Y}_{0.1} M_{0.1} O_{3-\delta}$ phases synthesized at $1350^{\circ} \mathrm{C}$ for $(A) M=F e,(B) M=C o,(C) M=N i$, and $(D) M=Y b$. The arrows in (D) represent the positions where the 201 and 221 peaks would be observed if the space group was Pnma (space group No. 62).

Figure 3. The total resistance (bulk + grain boundary + electrode) is used to calculate the conductivity of the investigated samples. At lower temperatures (Figure 3A), three distinct arcs are observed. At higher temperatures, although it seems that the two higher frequency arcs have merged into one arc, the impedance data can still be fitted better by using three RC units, as is shown in the inset of Figure 3B. The magnitude of the constant phase elements (CPE) is larger than values normally attributed to oxygen ion conductors and is close to the capacitance reported for the proton conductors (Petit and Tao, 2013). The conductivity $(\sigma)$ of the compounds was computed using Eq. 2:

$$
\sigma=\frac{l}{R \times A}
$$

where $l, R$, and $A$ are the thickness $(\mathrm{cm})$, total resistance $(\Omega)$, and cross sectional area $\left(\mathrm{cm}^{2}\right)$ of the cylindrical sample. Figure 4 shows the Arrhenius plots for the total conductivity of the compounds in air and $\mathrm{H}_{2}+3$ vol. $\% \mathrm{H}_{2} \mathrm{O}$ after sintering at 1250, 1350 , and $1550^{\circ} \mathrm{C}$. Among the 1250 (Figures 4A,D) and $1350^{\circ} \mathrm{C}$ (Figures 4B,E) sintered samples, the Ni-doped samples show a higher conductivity. However, by increasing the sintering temperature to $1550^{\circ} \mathrm{C}$, the Co-doped sample showed the highest conductivity $\left(0.01 \mathrm{~S} \mathrm{~cm}^{-1}\right.$ at $600^{\circ} \mathrm{C}$ in wet $\left.\mathrm{H}_{2}\right)$ (Figures $4 \mathrm{C}, \mathbf{F}$ ) of the new compounds synthesized in this study. The conductivity of the Co-doped sample in both air and wet $\mathrm{H}_{2}$ was found to increase by about 10 times by increasing sintering temperature by $300^{\circ} \mathrm{C}$, while the conductivity of the Ni-doped sample is suppressed by ca. 3 times. The Fe-doped sample does not show significant changes in conductivity, even after firing at $1550^{\circ} \mathrm{C}$, while the BZCY-Co compound, sintered at $1550^{\circ} \mathrm{C}$, shows the highest total conductivity of $2.6 \times 10^{-2} \mathrm{~S} \mathrm{~cm}^{-1}$ at $800^{\circ} \mathrm{C}$ in air.

\section{PHASE STABILITY AND SINTERABILITY}

The sinterability and phase stability of the as-synthesized compounds at three temperatures $\left(1250,1350\right.$, and $\left.1550^{\circ} \mathrm{C}\right)$ were also studied. To serve as a proton conductor electrolyte, materials such as BZCY-Yb and BZCY have generally been sintered at high temperatures, e.g., $1550^{\circ} \mathrm{C}$, to achieve the minimum porosity (Yang et al., 2009). Co-sintering of the anode and electrolyte, especially in anode-supported SOFCs, is a common cell fabrication method. During the co-sintering of these two materials, the anode materials are exposed to a temperature high enough to achieve electrolyte sintering, and thus their stability at these temperatures is necessary. Therefore, the effect of sintering at $1550^{\circ} \mathrm{C}$ on the chemical stability and microstructure of the synthesized compounds was investigated. As a reference, the sintering behavior of these compounds is compared with that of BZCY-Yb.

Figures $5 \mathrm{~A}-\mathrm{C}$ show the effect of the sintering temperature on the microstructure of the BZCY-Fe compound. While the sintering process has already started at $1250^{\circ} \mathrm{C}$, the dense sample is obtained at $1550^{\circ} \mathrm{C}$. The morphology of the BZCY-Ni and BZCYCo compounds after sintering at different temperatures is shown in Figures 5D-I, respectively. Both samples show a dense morphology even at $1250^{\circ} \mathrm{C}$, confirming the effect of $\mathrm{Ni}$ and $\mathrm{Co}$ as effective sintering aids. By increasing the sintering temperature, the grain size increases considerably. On the other hand, the sintering of the BZCY-Yb compound only begins at $1550^{\circ} \mathrm{C}$, and after 

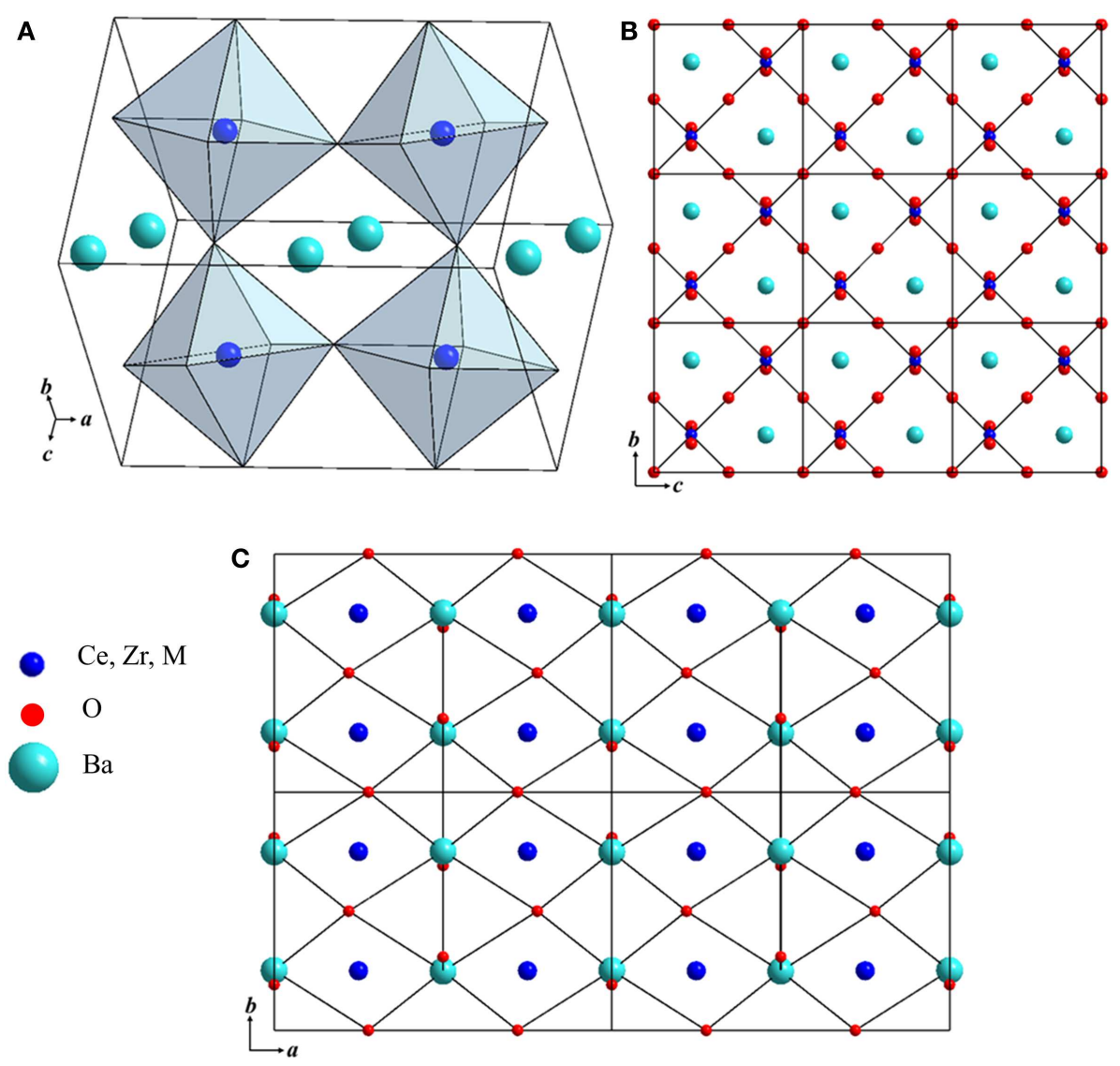

FIGURE 2 | (A) Crystal structure of BZCY-M. The corners of the octahedra are where oxygen ions are located, while the large green spheres represent the Ba atoms. (B) The crystal structure viewed through the a-axis, with the blue spheres showing the $\mathrm{Ce} / \mathrm{Zr} / \mathrm{Y} / \mathrm{M}$ atoms, green spheres representing $\mathrm{Ba}$, and red spheres oxygen. (C) The crystal structure viewed through the $c$-axis, where the Ba atoms are connected to their nearest oxygen atoms. Each oxygen is located between four $\mathrm{Ba}$ atoms.
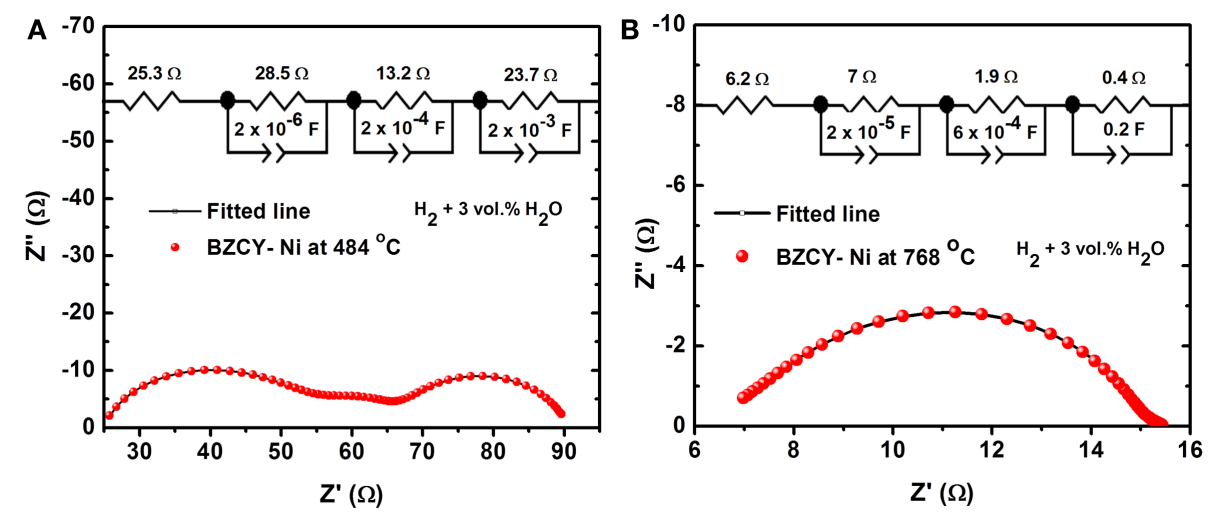

FIGURE 3 |Typical AC impedance spectra and fitted lines of the $\mathrm{BaZr}_{0.1} \mathrm{Ce}_{0.7} \mathrm{Y}_{0.1} \mathrm{Ni}_{0.1} \mathrm{O}_{3-\delta}$ compound at (A) $484^{\circ} \mathrm{C}$ and $(\mathrm{B}) 837^{\circ} \mathrm{C}$ in $\mathrm{H}_{2}+3$ vol.\% $\mathrm{H}_{2} \mathrm{O}$. The equivalent circuit and fitted data are shown in the inset.

$12 \mathrm{~h}$ of sintering at this temperature; the sample still has some porosity (Figure 5L). Comparing Figures 5J,K, it can be seen that the $1350^{\circ} \mathrm{C}$ sintering temperature has caused some grain growth, but without noticeable sintering of the BZCY-Yb sample. Also, considering Figures 5H,I, a secondary phase (marked with the letter " $\mathrm{S}$ ") is observable in the BZCY-Co sample. Observation of a 

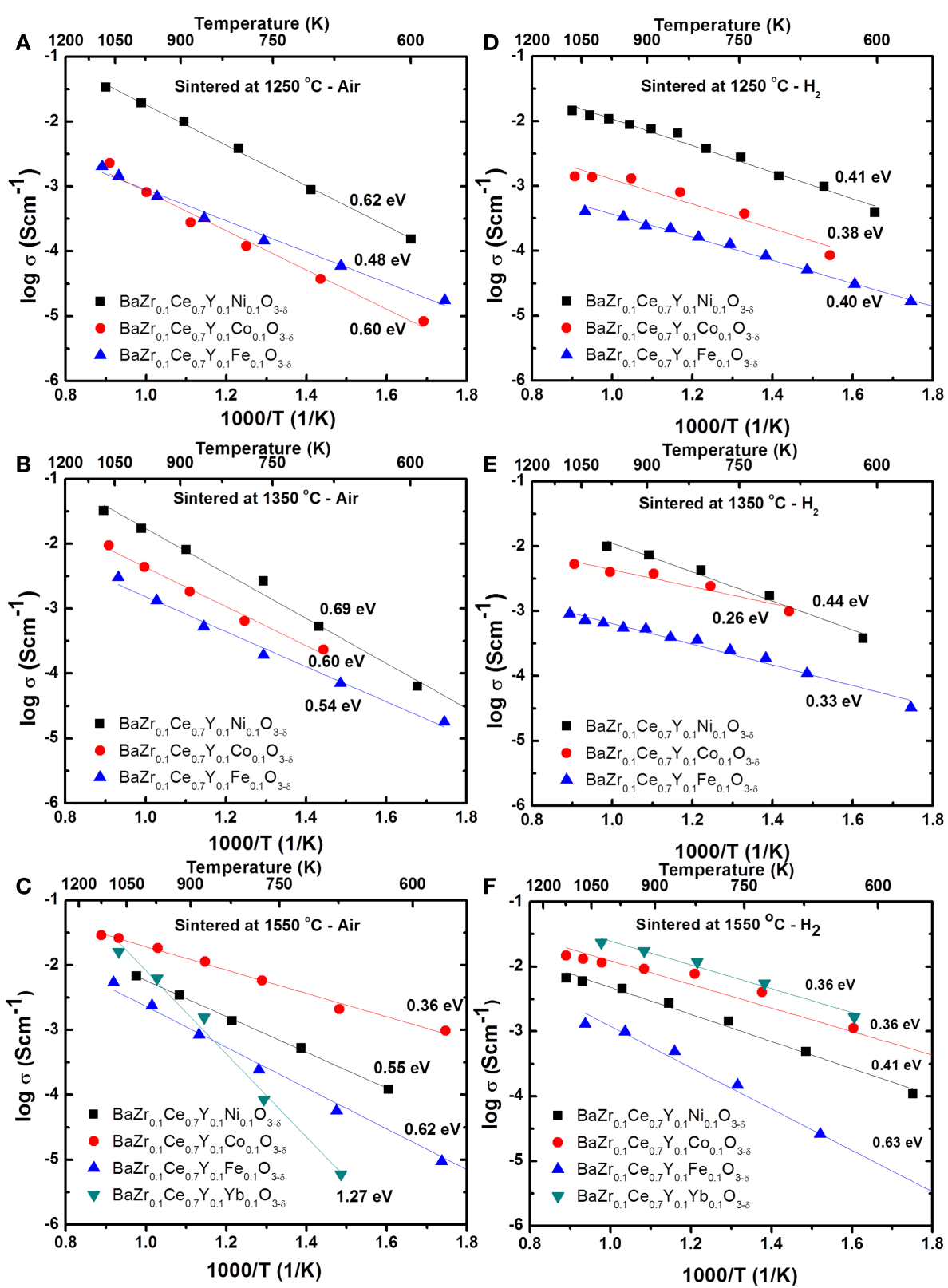

FIGURE 4 | Arrhenius plots for the total conductivity of the BZCY-M compounds in air (A-C) and $\mathrm{H}_{2}$ (with 3 vol.\% $\left.\mathrm{H}_{2} \mathrm{O}\right)(\mathrm{D}-\mathrm{F})$ after sintering at $1250^{\circ} \mathrm{C} / 24 \mathrm{~h}(\mathrm{~A}, \mathrm{D}), 1350^{\circ} \mathrm{C} / 24 \mathrm{~h}(\mathrm{~B}, \mathrm{E})$, and $1550^{\circ} \mathrm{C} / 12 \mathrm{~h}(\mathrm{C}, \mathrm{F})$.

$\mathrm{BaCoO}_{3}$ phase in a similar system has been reported in the literature (Yang et al., 2011). Based on the SEM image, the secondary phase seems to wet the BZCY-Co grains very well, running into the grain-boundaries. Similar to the BZCY-Co sample, the Ni-doped compound also shows a secondary phase (Figure 5F) after firing at $1550^{\circ} \mathrm{C}$ in air. However, no secondary phase is observed for the $\mathrm{Fe}$ - and $\mathrm{Yb}$-doped samples, even after firing at $1550^{\circ} \mathrm{C}$.

\section{CHEMICAL STABILITY}

The chemical stability of the Ni-, Co-, and Fe-doped BZCY-M compounds was studied in $\mathrm{CO}_{2} / \mathrm{N}_{2}(1: 2$ ratio) and in $30 \mathrm{ppm}$
$\mathrm{H}_{2} \mathrm{~S} / \mathrm{H}_{2}$ and results are shown in Figures 6 and 7, respectively. To eliminate the effect of the synthesis method on the stability, the BZCY compound was also synthesized using a similar method (at $1350^{\circ} \mathrm{C}$ ). The BZCY compound shows a minimal conversion to $\mathrm{BaCO}_{3}$, while the $1350^{\circ} \mathrm{C}$ synthesized doped BZCY$\mathrm{M}$ compounds start to gain weight in the temperature range of $450-500^{\circ} \mathrm{C}$ (Figure 6A). The decomposition process accelerates at around $600^{\circ} \mathrm{C}$ and, at $800^{\circ} \mathrm{C}$, reaches maximum values of 6 , 12,14 , and $17 \%$ conversion to $\mathrm{BaCO}_{3}$ for the BZCY-Fe, $-\mathrm{Ni}$, -Co, and - Yb-doped samples, respectively. Interestingly, except for the BZCY sample, the $\mathrm{CO}_{2}$ stability trend of the BZCY-M 

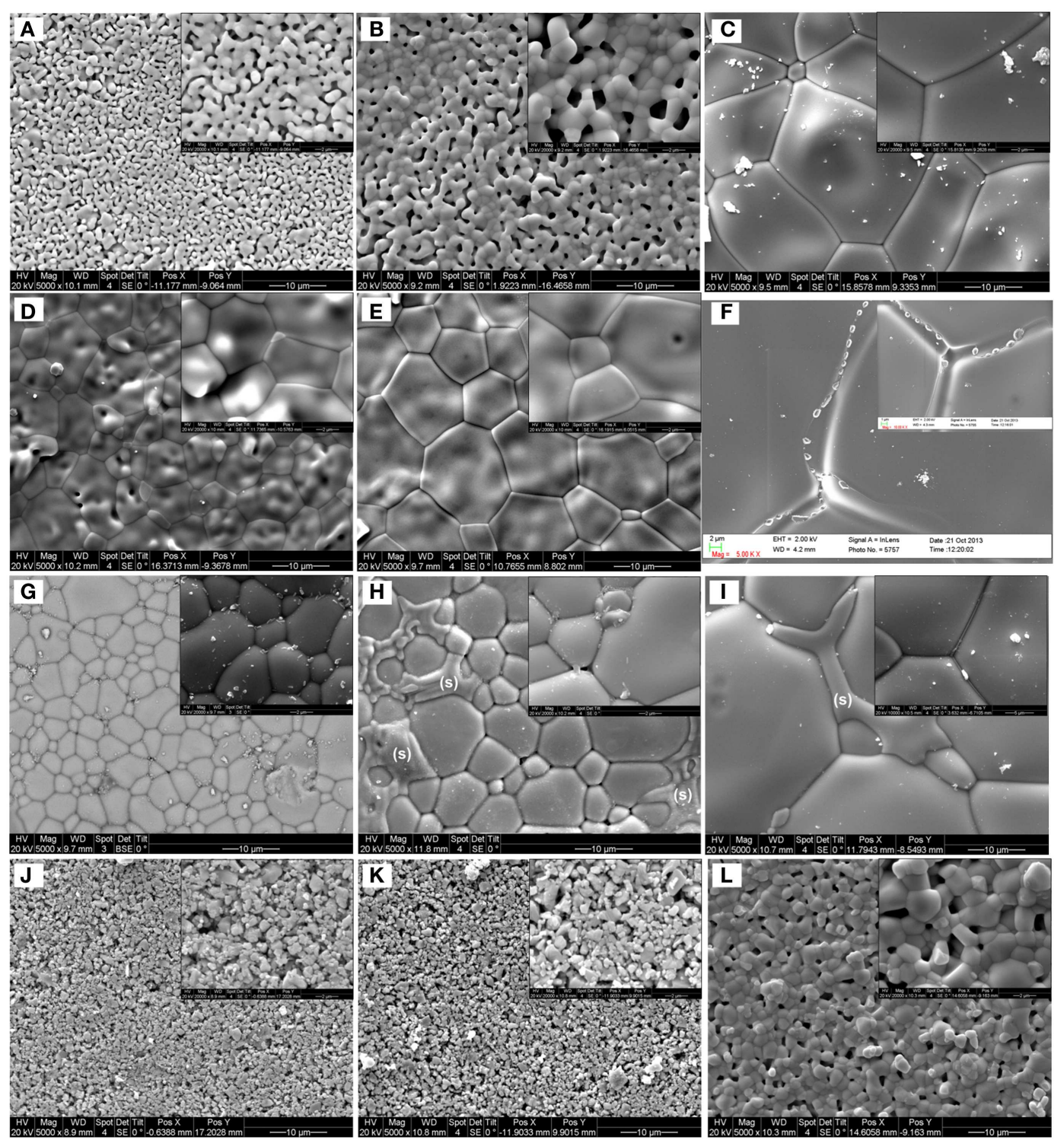

FIGURE 5 |Top-view SEM images of the BZCY-M pellet samples, with $M=F e(A-C), ~ N i(D-F), C o ~(G-I)$, and Yb (J-L) after firing at $1250^{\circ} \mathrm{C} / 24 \mathrm{~h}(A, D, G, J)$, $1350^{\circ} \mathbf{C} / \mathbf{2 4} \mathbf{h}(\mathbf{B}, \mathbf{E}, \mathbf{H}, \mathbf{K})$, and $1550^{\circ} \mathbf{C} / 12 \mathrm{~h}(\mathbf{C}, \mathbf{F}, \mathbf{I}, \mathbf{L})$ in air. The secondary phase in the BZCY-Co sample is marked with the letter " $\mathrm{S}^{\prime}$ in $(\mathbf{H}, \mathbf{I})$.

compounds follows the reverse pattern of the conductivity trend. While the BZCY-Yb and BZCY-Co samples show some of the highest conductivity values among the compounds examined here, they show the highest $\mathrm{CO}_{2}$ uptake and thus the lowest chemical stability. Similarly, the BZCY-Fe compound, with the lowest conductivity, illustrates a lower $\mathrm{CO}_{2}$ uptake and better stability. On the other hand, after the samples were fired at $1550^{\circ} \mathrm{C}$ for $12 \mathrm{~h}$, the chemical stability in $\mathrm{CO}_{2}$ has increased significantly, with the BZCY-Ni sample not gaining any measurable weight. The percent conversion of the Fe- and Co-doped samples to $\mathrm{BaCO}_{3}$ is also now less than $2 \%$, while the Yb-doped sample still exhibits greater decomposition, with a close to $6 \%$ conversion to $\mathrm{BaCO}_{3}$.
The chemical stability of the as-synthesized compounds was also studied in $30 \mathrm{ppm} \mathrm{H}_{2} \mathrm{~S}$ in a dry $\mathrm{H}_{2}$ atmosphere, with the ex situ XRD results are shown in Figure 7. After heating the BZCY, BZCY-Fe, Co, and Ni compounds in powder form at $800^{\circ} \mathrm{C}$ for $24 \mathrm{~h}$ in $30 \mathrm{ppm} \mathrm{H}_{2} \mathrm{~S}$ balanced with dry $\mathrm{H}_{2}$, no impurity phase is observed in the BZCY-Fe and -Co samples. In the BZCY-Ni XRD pattern, however, a weak peak for metallic $\mathrm{Ni}$ is observed [joint committee on powder diffraction standards (JCPDS) card no.: 45-1027], which could be related to the ex-solution of $\mathrm{Ni}$ after reduction in dry $\mathrm{H}_{2}$ at $800^{\circ} \mathrm{C}$. The BZCY synthesized in our lab showed small impurity peaks, however, after treatment in $30 \mathrm{ppm} \mathrm{H}_{2} \mathrm{~S} / \mathrm{H}_{2}$ at $800^{\circ} \mathrm{C}$ for $24 \mathrm{~h}$ no new phases were observed (Figure 7). 

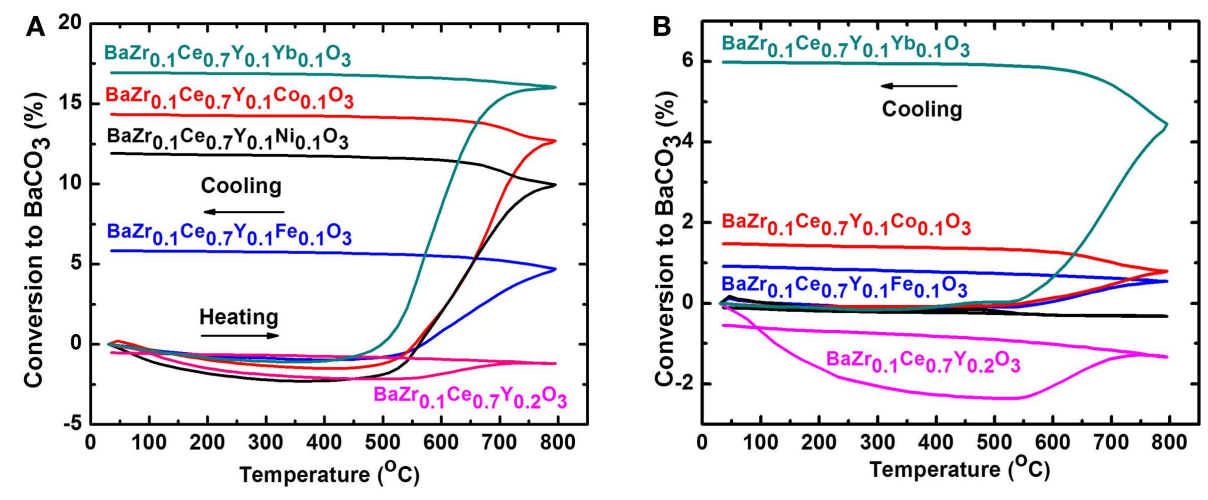

FIGURE 6 |Thermogravimetric analysis (TGA) in $\mathrm{CO}_{2} / \mathrm{N}_{2}\left(1: 2\right.$ ratio) at a $10^{\circ} \mathrm{C} / \mathrm{min}$ heating and cooling rate for $\mathrm{BaZr}_{0.1} \mathrm{Ce} \mathrm{e}_{0.7} \mathrm{Y}_{0.1} \mathrm{M}_{0.1} \mathrm{O}_{3-\delta}$ compounds $(\mathbf{M}=\mathbf{F e}, \mathbf{N i}, \mathbf{C o}, \mathbf{Y}$, and $\mathbf{Y b})$, synthesized at $1350^{\circ} \mathbf{C}(\mathbf{A})$ and after firing at $1550^{\circ} \mathbf{C}(\mathbf{B})$. In order to be able to compare the results, the particle size was controlled at below $150 \mu \mathrm{m}$ in both cases.

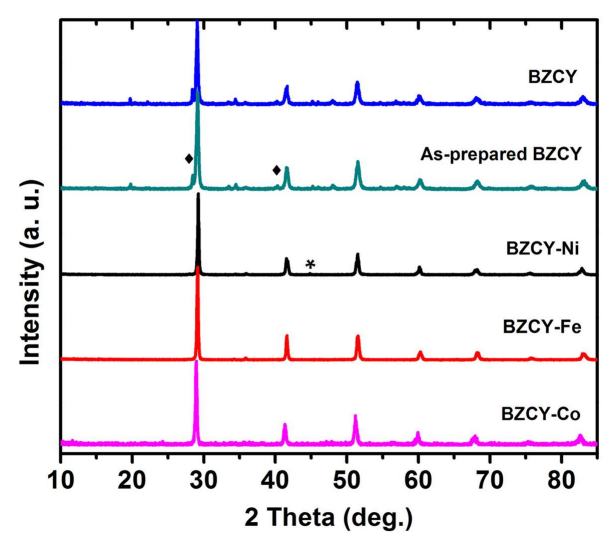

FIGURE 7 | XRD patterns of the BZCY, BZCY-Fe, -Co, and - Ni samples after testing for $24 \mathrm{~h}$ at $800^{\circ} \mathrm{C}$ in dry $\mathrm{H}_{2} / 30 \mathrm{ppm} \mathrm{H}_{2} \mathrm{~S}$. Small un-identified impurity phase peaks ( ) are observable in the as-prepared BZCY, which remain un-changed after $\mathrm{H}_{2} \mathrm{~S}$ treatment. ${ }^{*}$ Represents peak due to $\mathrm{Ni}$

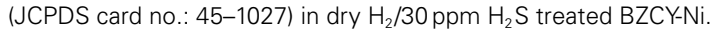

\section{DISCUSSION}

\section{STRUCTURAL CHARACTERIZATION}

Previous studies of the crystal structure of $\mathrm{BaCeO}_{3}$ at a range of temperatures has shown that a transition from the space group Pnma to Imam occurs at $290^{\circ} \mathrm{C}$ (Knight, 1994) or $300^{\circ} \mathrm{C}$ (Genet et al., 1999). This transition has been identified, based on the disappearance of the 201 and 221 peaks (Genet et al., 1999), which further confirms the space group Imam. In addition to the 201 and 221 peaks, another distinct Pnma peak, which is absent, is 131 that should be just below the 221 peak. The observation of the Imam space group is interesting, as in the parent compound $\left(\mathrm{BaCeO}_{3}\right)$, the occurrence of an Imam structure is triggered by the increase in temperature, while in $\mathrm{BaZr}_{0.1} \mathrm{Ce}_{0.7} \mathrm{Y}_{0.1} \mathrm{M}_{0.1} \mathrm{O}_{3-\delta}$, this space group is observed at room temperature (Figure 1).

This change in crystal symmetry as a result of doping has been observed previously, where a large amount of $\mathrm{Y}^{3+}$ has replaced $\mathrm{Ce}^{4+}$ in $\mathrm{BaCeO}_{3}$ (Malavasi et al., 2008). The $\mathrm{BaCe}_{0.8} \mathrm{Y}_{0.2} \mathrm{O}_{3-\delta}$ compound, with $20 \% \mathrm{Y}^{3+}$ doping, has been reported to have a monoclinic $I 2 / \mathrm{m}$ space group at room temperature (Malavasi et al., 2008), whereas, for $\mathrm{BaCe}_{0.9} \mathrm{Y}_{0.1} \mathrm{O}_{3-\delta}$ with $10 \%$ doping, a Pnma structure was reported at room temperature (Malavasi et al., 2009). The effect of doping has also been observed for $\mathrm{Nd}$-doped $\mathrm{BaCeO}_{3}$ (Knight, 1999), where 5\% doping has been shown to change the crystal symmetry from orthorhombic, Pnma, to tetragonal, $P 4 / \mathrm{mbm}$, while $10 \%$ doping results in the formation of the cubic space group $P m 3 m$. It appears that the disorder prompted by doping can lead to a similar outcome as the thermal effect. Also, the unit cell volume increases from 330.97(5) $\AA^{3}$ for the Fe-doped sample to $335.35(6) \AA^{3}$ for the Ni-doped sample and reaches a maximum of 337.26(7) $\AA^{3}$ in the $\mathrm{Yb}$-doped sample (Figure 1).

\section{EFFECT OF DOPANT AND SINTERING TEMPERATURE ON TOTAL CONDUCTIVITY AND STABILITY IN $\mathrm{CO}_{2}$}

The higher conductivity of the Ni-doped sample at lower sintering temperatures, compared to other samples studied here, may be related to the higher concentration of oxygen vacancies (in air) introduced into the crystal structure upon substitution of $\mathrm{Ni}^{2+}$ at the B-site of the perovskite material. The oxygen vacancies present in the structure could be transformed to proton charge carriers $\left(\mathrm{H}^{+}\right)$upon exposure to water in wet $\mathrm{H}_{2}$ (Eq. 1). In most cases, the activation energy associated with the conductivity of these materials in air is higher than in wet $\mathrm{H}_{2}$. While it is expected that some electronic conductivity is present in both atmospheres, the lower activation energy in wet $\mathrm{H}_{2}$ could be attributed to differences in the charge carriers, i.e., protons $\left(\mathrm{H}^{+}\right)$in wet $\mathrm{H}_{2}$ compared to oxygen ions $\left(\mathrm{O}^{2-}\right)$ in air. Due to their smaller size, proton transport has lower activation energy, providing a higher conductivity at lower temperatures, compared to oxygen ions.

Increasing the sintering temperature enhances the total conductivity of the BZCY-Co, as shown in Figure 8. This could be related to the formation of the Co-rich secondary phase (Figure 5H). Yang et al. (2011) have shown an increase in conductivity of the $\mathrm{BaZr}_{0.1} \mathrm{Ce}_{0.7} \mathrm{Y}_{0.2-x} \mathrm{Co}_{x} \mathrm{O}_{3-\delta}(0 \leq x \leq 0.2)$ compound with an increase in the Co content, attributing the higher conductivity values to the formation of $\mathrm{a} \mathrm{BCOO}_{3}$-based phase. The 

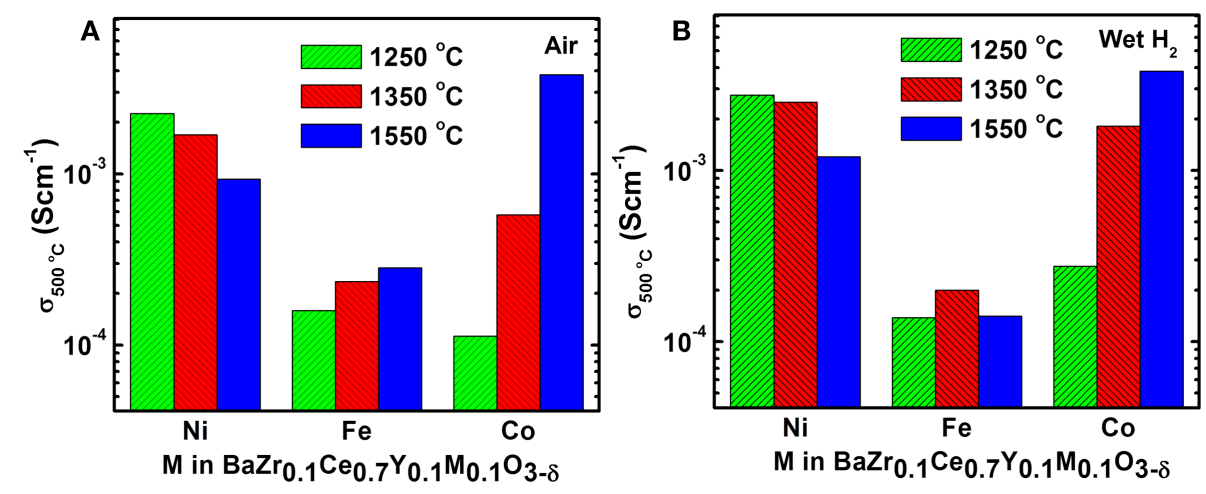

FIGURE 8 | Effect of sintering temperature and dopant type on electrical conductivity of $\mathrm{BZCY}-\mathrm{M}(\mathrm{M}=\mathrm{Fe}, \mathrm{Ni}$, and $\mathrm{Co})$ at $500^{\circ} \mathrm{C}$ in $(\mathrm{A})$ air and in $(\mathrm{B})$ wet $\mathrm{H}_{2}$.
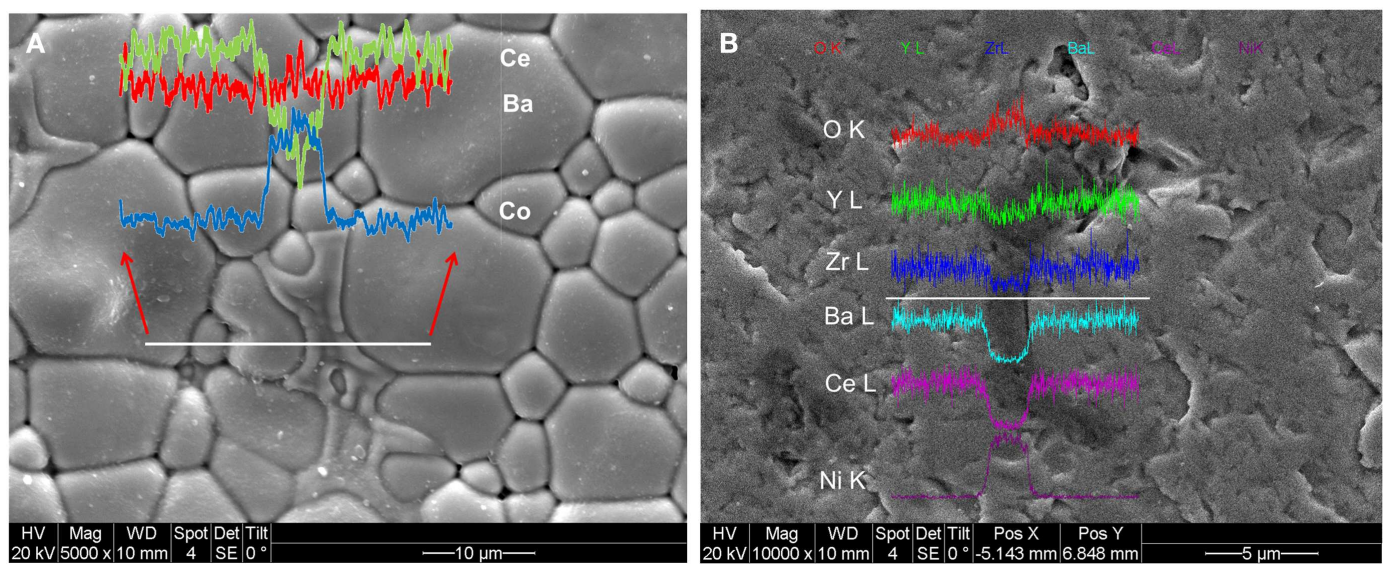

FIGURE 9 | SEM picture of (A) the surface of the BZCY-Co sample sintered at $1350^{\circ} \mathrm{C}$ and (B) polished surface of the BZCY-Ni sample sintered at $1550^{\circ} \mathrm{C}$. The results of line scan along the white line are shown in the inset.

$\mathrm{BaCoO}_{3}$ phase has a higher electronic conductivity compared to the parent BZCY phase.

To understand the chemical composition of the secondary phase, EDX line scans were collected across the grains, with the results shown in Figure 9. The inset in Figure 9A shows that the secondary phase has a high concentration of Co, but a decreased Ce content. The $\mathrm{Ba}$ concentration remains almost the same in both the primary and secondary phases, suggesting the formation of a $\mathrm{BaCoO}_{3}$-based perovskite. This result is also consistent with WDS study (not shown). It has been shown that, in $\mathrm{BaZr}_{0.1} \mathrm{Ce}_{0.7} \mathrm{Y}_{0.2-x} \mathrm{Co}_{x} \mathrm{O}_{3-\delta}$, a $\mathrm{BaCoO}_{3}$-based phase is observed in the XRD pattern when the Co content is about $10 \mathrm{~mol} \%$ (Yang et al., 2011). However, in contrast to our SEM images (Figures 5H,I and 9A) that clearly show the formation of the secondary phase, XRD results (Figure 1B) do not show the $\mathrm{BaCoO}_{3}$ peaks after synthesis at $1350^{\circ} \mathrm{C}$. This could be related to the lower concentration of the secondary phase in the present work. Yang et al. prepared single-phase $\mathrm{BaZr}_{0.1} \mathrm{Ce}_{0.7} \mathrm{Y}_{0.2-x} \mathrm{Co}_{x} \mathrm{O}_{3-\delta}$ after three times sintering and subsequent ball-milling at $1100^{\circ} \mathrm{C}$ for $10 \mathrm{~h}$. However, in this study the BZCY-Co single-phase was obtained after firing at $1350^{\circ} \mathrm{C}$. Calcination at $1350^{\circ} \mathrm{C}$ may have caused some Co evaporation from the compound, as blue color associated with Co was observed on the alumina crucible. This may have decreased the Co content and lowered the concentration of the $\mathrm{BaCoO}_{3}$ phase below the XRD detection limit.

In contrast to the Co-doped sample, the conductivity of the BZCY-Ni compound decreases with increasing sintering temperature. At $1550^{\circ} \mathrm{C}$, the sub-micron sized $\mathrm{NiO}$ particles can be observed at the grain-boundaries (Figure 5F), with their chemical composition confirmed by EDX analysis. A subsequent EDX line scan study on these phases confirmed that $\mathrm{Ni}$ and oxygen are the only elements present (Figure 9B). The ex-solution of metals at high temperatures from perovskite materials upon reduction has been reported recently (Neagu et al., 2013). This may have caused the lower conductivity of the BZCY-Ni sample after sintering at $1550^{\circ} \mathrm{C}$, compared to the sample fired at two lower temperatures (Figure 8).

The enhanced tolerance of the samples fired at $1550^{\circ} \mathrm{C}$ toward $\mathrm{CO}_{2}$ exposure may have been caused by $\mathrm{Ba}$ evaporation during heat treatment at higher temperature, which makes these 


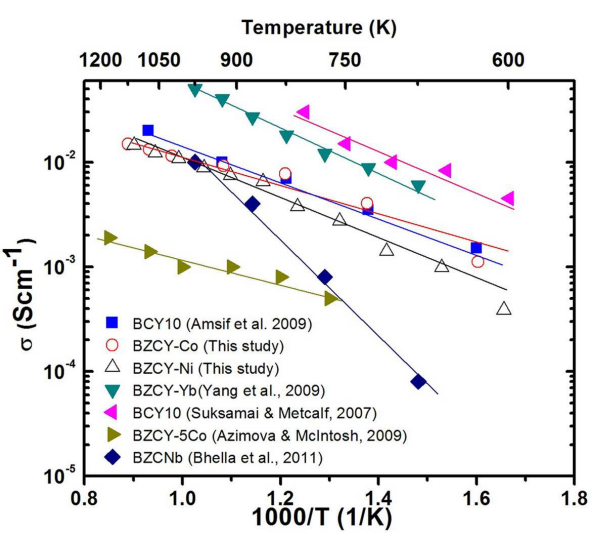

FIGURE 10 | Comparison of the reported conductivity values for barium cerate based perovskite SOFC materials in wet $\mathrm{H}_{2}$ atmosphere. In the figure, BCY 10, BZCY-Co, BZCY-Ni, BZCY-Yb, BZCY-5Co, and BZCNb represent $\mathrm{BaCe}_{0.9} \mathrm{Y}_{0.1} \mathrm{O}_{3-\delta}$ (Suksamai and Metcalfe, 2007; Amsif et al., 2011), $\mathrm{BaZr}_{0.1} \mathrm{Ce}_{0.7} \mathrm{Y}_{0.1} \mathrm{Co}_{0.1} \mathrm{O}_{3-\delta}$ sintered at $1550^{\circ} \mathrm{C}, \mathrm{BaZr}_{0.1} \mathrm{Ce}_{0.7} \mathrm{Y}_{0.1} \mathrm{Ni}_{0.1} \mathrm{O}_{3-\delta}$ sintered at $1250^{\circ} \mathrm{C}, \mathrm{BaZr}_{0.1} \mathrm{Ce}_{0.7} \mathrm{Y}_{0.1} \mathrm{Yb}_{0.1} \mathrm{O}_{3-\delta}$ (Yang et al., 2009),

$\mathrm{BaZr}_{0.4} \mathrm{Ce}_{0.5} \mathrm{Y}_{0.05} \mathrm{Co}_{0.05} \mathrm{O}_{3-8}$ (Azimova and McIntosh, 2009), and

$\mathrm{BaZr}_{0.1} \mathrm{Ce}_{0.8} \mathrm{Nb}_{0.1} \mathrm{O}_{3-\delta}$ (Bhella et al., 2011), respectively.

compounds $\mathrm{Ba}$ deficient and hence less prone to reaction with $\mathrm{CO}_{2}$. Although the particle size of the powders used for the two tests is very similar, the samples that were heat treated at $1550^{\circ} \mathrm{C}$ have larger grain sizes and fewer grain-boundaries, as shown in Figure 5.

In summary, the BZCY-Co compound, studied here, shows a very promising electrical conductivity compared to other compounds arising from the same perovskite family (Figure 10), especially at intermediate temperatures $\left(0.01 \mathrm{~S} \mathrm{~cm}^{-1}\right.$ at $600^{\circ} \mathrm{C}$ in wet $\mathrm{H}_{2}$ ). Thus, BZCY-Co is considered to be a very promising candidate anode material for SOFCs. The higher sintering temperature of $1550^{\circ} \mathrm{C}$ enhances the total conductivity of the BZCY-Co compound, due to the formation of a $\mathrm{BaCoO}_{3}$-based secondary phase. However, the highest conductivity within the BZCY-Ni samples is observed for the sample fired at the lowest sintering temperature of $1250^{\circ} \mathrm{C}$. Ni ex-solution from the BZCY-Ni sample is observed after sintering at $1550^{\circ} \mathrm{C}$ for $12 \mathrm{~h}$ and seems to be responsible for the conductivity loss, as a result of bulk composition change. Also, sintering at the higher temperature of $1550^{\circ} \mathrm{C}$ enhances the stability of the compound in the $\mathrm{CO}_{2}$-containing environment.

\section{ACKNOWLEDGMENTS}

The authors would like to acknowledge financial support from the Natural Sciences and Engineering Research Council of Canada (NSERC) through the Strategic Research Network (Solid Oxide Fuel Cells Canada) Granting Program and the Institute for Sustainable Energy, Environment and Economy (ISEEE) at the University of Calgary. One of us (Behzad Mirfakhraei) is also grateful for NSERC PGSD scholarship support. We also would like to acknowledge the services of the Microscopy and Imaging Facility at the University of Calgary, access to Field-Emission SEM facilities at the University of Calgary, and Parastoo Keyvanfar for help with SEM analysis and useful discussions.

\section{REFERENCES}

Amsif, M., Marrero-Lopez, D., Ruiz-Morales, J. C., Savvin, S. N., Gabás, M., and Nunez, P. (2011). Influence of rare-earth doping on the microstructure and conductivity of $\mathrm{BaCe}_{0.9} \mathrm{Ln}_{0.1} \mathrm{O}_{3-\delta}$ proton conductors. J. Power Sources 196, 3461-3469. doi:10.1016/j.jpowsour.2010.11.120

Azimova, M. A., and McIntosh, S. (2009). Transport properties and stability of cobalt doped proton conducting oxides. Solid State Ionics 180, 160-167. doi:10.1016/j.ssi.2008.12.013

Bhella, S. S., Fürstenhaupt, T., Paul, R., and Thangadurai, V. (2011). Synthesis, structure, chemical stability, and electrical properties of $\mathrm{Nb}-, \mathrm{Zr}-$, and $\mathrm{Nb}$-Codoped $\mathrm{BaCeO}_{3}$ perovskites. Inorg. Chem. 50, 6493-6499. doi:10.1021/ic201008v

Genet, F., Loridant, S., Ritter, C., and Lucazeau, G. (1999). Phase transitions in $\mathrm{BaCeO}_{3}$ : neutron diffraction and Raman studies. J. Phys. Chem. Solids 60 2009-2021. doi:10.1016/S0022-3697(99)00031-1

Iwahara, H., Esaka, T., Uchida, H., and Maeda, N. (1981). Proton conduction in sintered oxides and its application to steam electrolysis for hydrogen production. Solid State Ionics 359-363. doi:10.1016/0167-2738(81)90113-2

Knight, K. S. (1994). Structural phase transitions in $\mathrm{BaCeO}_{3}$. Solid State Ionics 74, 109-117. doi:10.1016/0167-2738(94)90199-6

Knight, K. S. (1999). Oxygen vacancy ordering in neodymium-doped barium cerate. Solid State Commun. 112, 73-78. doi:10.1016/S0038-1098(99)00290-2

Knight, K. S., and Bonanos, N. (1995). The crystal structures of some doped and undoped alkaline earth cerate perovskites. Mater. Res. Bull. 30, 347-356. doi:10.1016/0025-5408(95)00009-7

Kreuer, K. D. (1999). Aspects of the formation and mobility of protonic charge carriers and the stability of perovskite-type oxides. Solid State Ionics 125, 285-302. doi:10.1016/S0167-2738(99)00188-5

Larson, A. C., and Von Dreele, R. B. (1994). General structure analysis system (GSAS). New Mexico: Los Alamos National Laboratory Report LAUR.

Liu, Y., Yang, L., Liu, M., Tang, Z., and Liu, M. (2011). Enhanced sinterability of $\mathrm{BaZr}_{0.1} \mathrm{Ce}_{0.7} \mathrm{Y}_{0.1} \mathrm{Yb}_{0.1} \mathrm{O}_{3-\delta}$ by addition of nickel oxide. J. Power Sources 196, 9980-9984. doi:10.1016/j.jpowsour.2011.08.047

Malavasi, L., Kim, H., and Proffen, T. (2009). Local and average structures of the proton conducting Y-doped $\mathrm{BaCeO}_{3}$ from neutron diffraction and neutron pair distribution function analysis. J. Appl. Phys. 105, 123519-123519. doi:10.1063/1.3148864

Malavasi, L., Ritter, C., and Chiodelli, G. (2008). Correlation between thermal properties, electrical conductivity, and crystal structure in the $\mathrm{BaCe}_{0.8} \mathrm{Y}_{0.2} \mathrm{O}_{2.9}$ proton conductor. Chem. Mater. 20, 2343-2351. doi:10.1021/cm7033917

Neagu, D., Tsekouras, G., Miller, D. N., Ménard, H., and Irvine, J. T. (2013). In situ growth of nanoparticles through control of non-stoichiometry. Nat. Chem. 5, 916-923. doi:10.1038/nchem.1773

Nguyen, N. T. Q., and Yoon, H. H. (2013). Preparation and evaluation of $\mathrm{BaZr}_{0.1} \mathrm{Ce}_{0.7} \mathrm{Y}_{0.1} \mathrm{Yb}_{0.1} \mathrm{O}_{3-\delta}$ (BZCYYb) electrolyte and BZCYYb-based solid oxide fuel cells. J. Power Sources 231, 213-218. doi:10.1016/j.jpowsour.2013.01.011

Pergolesi, D., Fabbri, E., D’Epifanio, A., Di Bartolomeo, E., Tebano, A., Sanna, S., et al. (2010). High proton conduction in grain-boundary-free yttrium-doped barium zirconate films grown by pulsed laser deposition. Nat. Mater. 9, 846-852. doi: $10.1038 /$ nmat 2837

Petit, C. T. G., and Tao, S. (2013). Structure and conductivity of praseodymium and yttrium co-doped barium cerates. Solid State Sci. 17, 115-121. doi:10.1016/ j.solidstatesciences.2012.12.004

Ricote, S., and Bonanos, N. (2010). Enhanced sintering and conductivity study of cobalt or nickel doped solid solution of barium cerate and zirconate. Solid State Ionics 181, 694-700. doi:10.1016/j.ssi.2010.04.007

Ryu, K. H., and Haile, S. M. (1999). Chemical stability and proton conductivity of doped $\mathrm{BaCeO}_{3}-\mathrm{BaZrO}_{3}$ solid solutions. Solid State Ionics 125, 355-367. doi:10.1016/S0167-2738(99)00196-4

Schober, T. (2003). Applications of oxidic high-temperature proton conductors. Solid State Ionics 16, 277-281. doi:10.1016/S0167-2738(03)00241-8

Shannon, R. D. (1976). Revised effective ionic radii and systematic studies of interatomic distances in halides and chalcogenides. Acta Crystallogr. A 32, 751-767. doi:10.1107/S0567739476001551

Shimura, T., Tanaka, H., Matsumoto, H., and Yogo, T. (2005). Influence of the transition-metal doping on conductivity of $\mathrm{a} \mathrm{BaCeO}_{3}$-based protonic conductor. Solid State Ionics 176, 2945-2950. doi:10.1016/j.ssi.2005.09.027

Suksamai, W., and Metcalfe, I. S. (2007). Measurement of proton and oxide ion fluxes in a working Y-doped $\mathrm{BaCeO}_{3}$ SOFC. Solid State Ionics 178, 627-634. doi:10.1016/j.ssi.2007.02.003 
Tao, S. W., and Irvine, J. T. S. (2006). A stable, easily sintered proton-conducting oxide electrolyte for moderate-temperature fuel cells and electrolyzers. Adv. Mater. Weinheim 18, 1581-1584. doi:10.1002/adma.200502098

Toby, B. H. (2001). EXPGUI, a graphical user interface for GSAS. J. Appl. Crystallogr. 34, 210-213. doi:10.1016/j.jpba.2013.08.035

Trobec, F., and Thangadurai, V. (2008). Transformation of proton-conducting perovskite-type into fluorite-type fast oxide ion electrolytes using a $\mathrm{CO}_{2}$ capture technique and their electrical properties. Inorg. Chem. 47, 8972-8984. doi:10.1021/ic8010025

Tu, C. S., Chien, R. R., Lee, S. C., Tsai, C. L., Schmidt, V. H., Keith, A., et al. (2009). “Insitu temperature-dependent $\mathrm{X}$-ray diffraction study of $\mathrm{Ba}\left(\mathrm{Zr}_{0.8-\mathrm{x}} \mathrm{Ce}_{\mathrm{X}} \mathrm{Y}_{0.2}\right) \mathrm{O}_{3-\delta}$ ceramics," in Advances in Solid Oxide Fuel Cells IV: Ceramic Engineering and Science Proceedings, Vol. 29, Issue 5, eds T. Ohji and A. Wereszczak (Hoboken, NJ: John Wiley \& Sons, Inc.), 117-23.

Yang, L., Wang, S., Blinn, K., Liu, M., Liu, Z., Cheng, Z., et al. (2009). Enhanced sulfur and coking tolerance of a mixed ion conductor for SOFCs: $\mathrm{BaZr}_{0.1} \mathrm{Ce}_{0.7} \mathrm{Y}_{0.2-\mathrm{x}} \mathrm{Yb}_{\mathrm{x}} \mathrm{O}_{3-\delta}$. Science 326, 126-129. doi:10.1126/science.1174811

Yang, L., Wang, S., Lou, X., and Liu, M. (2011). Electrical conductivity and electrochemical performance of cobalt-doped $\mathrm{BaZr}_{0.1} \mathrm{Ce}_{0.7} \mathrm{Y}_{0.2} \mathrm{O}_{3-\delta}$ cathode. Int. J. Hydrogen Energy 36, 2266-2270. doi:10.1016/j.ijhydene.2010.11.053

Yang, L., Zuo, C., and Liu, M. (2010). High-performance anode-supported solid oxide fuel cells based on $\mathrm{Ba}\left(\mathrm{Zr}_{0.1} \mathrm{Ce}_{0.7} \mathrm{Y}_{0.2}\right) \mathrm{O}_{3-\delta}$ (BZCY) fabricated by a modified co-pressing process. J. Power Sources 195, 1845-1848. doi:10.1016/j.jpowsour. 2009.10.018

Zhang, J.-T., Liang, F.-L., Chi, B., Pu, J., and Jian, L. (2012). Enhanced electrochemical performance of $\mathrm{BaZr}_{0.1} \mathrm{Ce}_{0.7} \mathrm{Y}_{0.1} \mathrm{Yb}_{0.1} \mathrm{O}_{3-\delta}$ electrodes for hydrogen and methane oxidation in solid oxide fuel cells by $\mathrm{Pd}$ or $\mathrm{Cu}_{0.5} \mathrm{Pd}_{0.5}$ impregnation. J. Power Sources 200, 29-33. doi:10.1016/j.jpowsour.2011.10.082

Zhao, F., Liu, Q., Wang, S., Brinkman, K., and Chen, F. (2010). Synthesis and characterization of $\mathrm{BaIn}_{0.3-\mathrm{x}} \mathrm{Y}_{\mathrm{x}} \mathrm{Ce}_{0.7} \mathrm{O}_{3-\delta}(\mathrm{x} 0,0.1,0.2,0.3)$ proton conductors. Int. J. Hydrogen Energy 35, 4258-4263. doi:10.1016/j.ijhydene.2010. 02.080

Zhong, Z. (2007). Stability and conductivity study of the $\mathrm{BaCe}_{0.9-\mathrm{x}} \mathrm{Zr}_{\mathrm{x}} \mathrm{Y}_{0.1} \mathrm{O}_{2.95}$ systems. Solid State Ionics 178, 213-220. doi:10.1016/j.ssi.2006.12.007

Zuo, C., Dorris, S. E., Balachandran, U., and Liu, M. (2006a). Effect of Zr-doping on the chemical stability and hydrogen permeation of the $\mathrm{Ni}-\mathrm{BaCe}_{0.8} \mathrm{Y}_{0.2} \mathrm{O}_{3-\alpha}$ mixed protonic-electronic conductor. Chem. Mater. 18, 4647-4650. doi:10.1021/ $\mathrm{cm} 0518224$

Zuo, C., Zha, S., Liu, M., Hatano, M., and Uchiyama, M. (2006b). $\mathrm{Ba}\left(\mathrm{Zr}_{0.1} \mathrm{Ce}_{0.7} \mathrm{Y}_{0.2}\right) \mathrm{O}_{3-\delta}$ as an electrolyte for low-temperature solid oxide fuel cells. Adv. Mater. Weinheim 18, 3318-3320. doi:10.1002/adma.200601366

Conflict of Interest Statement: The authors declare that the research was conducted in the absence of any commercial or financial relationships that could be construed as a potential conflict of interest.

Received: 03 January 2014; paper pending published: 30 January 2014; accepted: 17 February 2014; published online: 13 March 2014.

Citation: Mirfakhraei B, Ramezanipour F, Paulson S, Birss V and Thangadurai V (2014) Effect of sintering temperature on microstructure, chemical stability, and electrical properties of transition metal or $\mathrm{Yb}$-doped $\mathrm{BaZr}_{0.1} \mathrm{Ce}_{0.7} \mathrm{Y}_{0.1} \mathrm{M}_{0.1} \mathrm{O}_{3-\delta}(\mathrm{M}=\mathrm{Fe}$, $\mathrm{Ni}$, Co, and $\mathrm{Yb}$ ). Front. Energy Res. 2:9. doi: 10.3389/fenrg.2014.00009

This article was submitted to Fuel Cells, a section of the journal Frontiers in Energy Research.

Copyright (c) 2014 Mirfakhraei, Ramezanipour, Paulson, Birss and Thangadurai. This is an open-access article distributed under the terms of the Creative Commons Attribution License (CC BY). The use, distribution or reproduction in other forums is permitted, provided the original author(s) or licensor are credited and that the original publication in this journal is cited, in accordance with accepted academic practice. No use, distribution or reproduction is permitted which does not comply with these terms. 